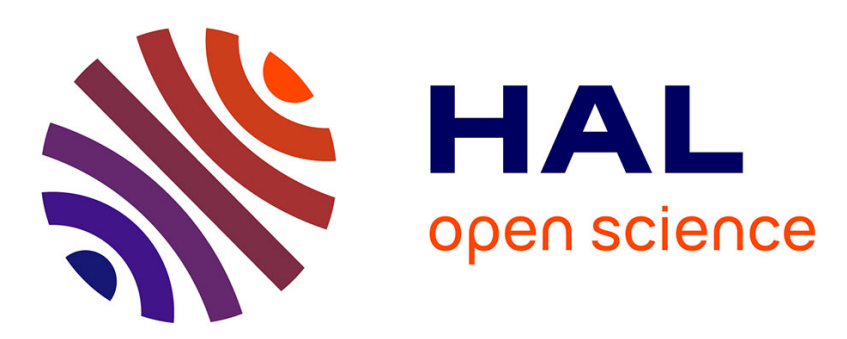

\title{
Managing an everlastingly polluted world. Food Policies and community health actions in the French West Indies
}

Didier Torny

\section{To cite this version:}

Didier Torny. Managing an everlastingly polluted world. Food Policies and community health actions in the French West Indies. Soraya Boudia; Nathalie Jas. Toxicants, Health and Regulation since 1945, Pickering \& Chatto, pp.117-134, 2013, 978-1848934030. halshs-01247022

\section{HAL Id: halshs-01247022 \\ https://shs.hal.science/halshs-01247022}

Submitted on 21 Dec 2015

HAL is a multi-disciplinary open access archive for the deposit and dissemination of scientific research documents, whether they are published or not. The documents may come from teaching and research institutions in France or abroad, or from public or private research centers.
L'archive ouverte pluridisciplinaire HAL, est destinée au dépôt et à la diffusion de documents scientifiques de niveau recherche, publiés ou non, émanant des établissements d'enseignement et de recherche français ou étrangers, des laboratoires publics ou privés.

\section{(c)(1)}

Distributed under a Creative Commons Attribution| 4.0 International License 
MANAGING AN EVERLASTINGLY POLLUTED WORLD.

FOOD POLICIES AND COMMUNITY HEALTH ACTIONS IN THE FRENCH WEST

INDIES

\section{Didier Torny ${ }^{1}$}

in Soraya Boudia, Nathalie Jas (dir.), Toxic World. Toxicants, Health and Regulation in the XXth Century, Pickering \& Chatto, 2013, p. 117-134.

INRA thus feels that whilst soil pollution by HCH will no longer be an issue in 2010, it will nevertheless take several centuries for drainage waters to slowly cleanse the earth and put an end to chlordecone pollution.

$(\text { Beaugendre })^{2}$

\section{Introduction}

What if policy makers took seriously the fact that we live in a permanently polluted world, ${ }^{3}$ rather than considering pollution to be harmless, negligible or easily manageable? What would be the consequences of such an attitude? Since the end of the 1990s, the rediscovery of chlordecone in the surface waters of the French West Indies has given us a small laboratory with which to answer these questions, by looking at how authorities have attempted to ensure that people live in safety. Chlordecone is a pesticide which until 1993 was used to fight banana weevils; it remains almost permanently in the soil and is only very slowly drained away. Whilst environmental pollution is not disputed as and when it is discovered, the issue of the health consequences of such pollution continues to be hotly debated. The toxicity of high doses of chlordecone is well-established, due to the massive production of epidemiological 
and toxicological knowledge following the Hopewell factory disaster in 1975, leading to it being banned in the United States. The West Indian case raises the issue of its possible harmful effects (cancers, fertility) at low doses, following exposure over a very long period.

Of course, the question of low dosage has been raised for many different substances, from food additives ${ }^{4}$ to radioactive elements, ${ }^{5}$ and chemical substances have been a focal point of different standards introduced over the last fifty years ${ }^{6}$, in order to determine the conditions under which a substance is qualified as harmless. This regulatory science ${ }^{7}$ is largely based on toxicological knowledge, shaped within laboratories, and in a few cases reinforced by epidemiological data. Conversely, knowledge from the field, focusing on actual exposure and its consequences, often remains controversial both in its methods and its results, even when produced by experts such as environmental health academics. ${ }^{8}$ It is therefore often replaced by reductionist approaches ${ }^{9}$ in the regulatory space, catastrophes and their subsequent trials being the main places where those different strains of knowledge confront one another. ${ }^{10}$ Whilst social movements built around polluted sites or regions need science for their claims to be heard, ${ }^{11}$ their aims are potentially more diverse, as the term 'environmental justice' suggests, and include notions such as the achievement of concrete results which directly impact at-risk communities. ${ }^{12}$

The chlordecone case involves all of the elements found in the literature, but within a very specific configuration based on two precise characteristics. Firstly, it is the story of extensive pollution being gradually rediscovered through systems of measurement and not of a case which was triggered by the gathering of syndromes where popular epidemiology plays a significant role. ${ }^{13}$

Secondly, it is a case which is completely dominated by a single main actor, the French government, which through its different institutions and programs plays every role from data gatherer and standard setter to norm enforcer and community health organizer. This article analyzes how France managed the pollution - accepted as lasting for centuries- and how local and global knowledge, from both the field and laboratories, are intertwined in order to limit the threat to human health while people continue to live in a contaminated environment.

To this end, after describing the gradual discovery of the presence of chlordecone in different milieus and the associated health issues (water pollution, soil contamination, food 
contamination), we will focus on the question of standards relating to foodstuffs. We will base ourselves on three source types: firstly, various official sources, from Snegaroff's publication in 1977 to AFFSA's (French agency for food safety) most recent opinions on nursing in 2008, along with reports from local consultation groups and parliamentary work. Secondly, sources from the actors who are either involved in the issue (associations, farming professionals, etc.) or who report on its progress (local or national press). Thirdly, we used elements reported by our contacts, especially in regard to an expert investigation in the French West Indies in October 2008.

\section{1/ From invisibility to full-scale pollution: building the tangibility of chlordecone}

The story of chlordecone is not one of the invisibilizsation of the pollution, ${ }^{14}$ but of a revisibilization process which began with water and which made the forgotten pesticide a tangible pollution. ${ }^{15}$ This visibilisation process also made it possible to retrace the history of the authorisation and use of chlordecone between 1964 and 1993, which we will summarise before moving on to the rediscovery of its presence in the environment.

After four years of study in the French West Indies, in 1968 two companies requested authorisation for sale in France under the Kepone brand name. ${ }^{16}$ Within an international context of discussions on the persistence of DDT, the risks to the environment had already been highlighted by the Commission des Toxiques, which was in charge of assessing pesticide toxicity at that time, and the request was refused at the end of 1969. Nonetheless, two years later Kepone was granted a temporary authorisation for sale whilst its competitors, fighting the banana weevil with $\mathrm{HCH}$ derivatives, had theirs rescinded. It consequently became the most used substance as from 1974. The Hopewell accident did nothing to modify France's regulatory attitude, and Kepone's authorisation for sale was regularly renewed until 1980. It was only when the product became unavailable due to its production being prohibited by the Environmental Protection Agency that the French importer stopped requesting authorisations for sale.

After being severely affected by two cyclones in 1980 and 1981 and having exhausted their stocks of Kepone, banana producers had to cope with a proliferation of the banana weevil. Within such a tense economic context and without any reference ever being made to 
American data or decisions, in 1981 the Commission des Toxiques granted an authorisation for Curlone, a new chlordecone formula. Upon request from French importers, Curlone was produced by a Brazilian company until the substance was banned in February 1990. However, the general provisions governing substances allowed sales to continue for a further two years; chlordecone was therefore used in the French West Indies until $1993 .{ }^{17}$ It was at the moment this ceased that environmental monitoring of water was introduced.

Indeed, the presence of pesticides in the surface waters of the French West Indies had been sought on various occasions as part of research projects, but it was as from 1991 that they were monitored on a routine basis in Martinique. Only some of the 500 substances approved in France for crop treatment ${ }^{18}$ were scrutinised, which is to be expected given the fact that numerous crops found in mainland France are not grown in the West Indies. However, as the Balland, Mestre and Fagot report ${ }^{19}$ points out, 'some very commonly used molecules are not monitored.' So whilst the results appear relatively satisfactory for the period in question, at least with regard to treated waters, the limited analytical capacities create two problems: it is impossible to continuously measure water pollution and it is impossible to measure the presence of certain molecules used on a local basis. In Guadeloupe, the situation is even more problematical, because pesticides 'are not monitored as part of health checks.'20 Contamination is only measured when it is caused by accidents or when a study is carried out. This highly critical report thus asserts the need to limit sources of pollution, to protect catchments and to improve water monitoring, especially by developing local ability to do analyses, the aim of these steps being to ensure public health and the protection of the environment in a serious situation where the principle of precaution is explicitly mentioned. The conclusions of the report led to campaigns for stronger measures in 1998 and 1999, both in Guadeloupe and Martinique, each country having basin committees since 1996, said committees becoming the central arena for discussing the analyses. In this critical context, chlordecone was very much on the fringe compared to other pesticides. ${ }^{21}$ It was only when analytical capacities were changed that it became a major subject of concern, standing out from most other pesticides whose contamination of surface waters was proven and worrying. 


\section{Discovery of the chlordecone problem: waters polluted by previous pesticides}

By setting up a new partnership with a laboratory from the Drôme region in France, capable of measuring 220 molecules and of funding a major measurement campaign in seven catchments in 1999, the Martinique DSDS (department of health and social development) considerably modified the analytical landscape and, at the same time, understanding of the contamination of both surface and underground waters, both raw and treated. The initial analyses showed high levels of contamination, particularly of $\mathrm{HCH} \beta$ (Hexachlorocyclohexane $\beta$ ), but the laboratory also discovered a 'peak' of contamination which required further analysis and which proved to be chlordecone, which is not searched for under standard practices and which is difficult to quantify. A similar study was carried out in Guadeloupe, with the same results. In February 2000, shortly after the Martinique alerts had led to the closure of a catchment (July 1999), the results of the campaign to take samples from the Guadeloupe catchments caused a 'crisis'. It would seem that this was the first time that an impact on public health had been declared by a French authority. The result was a shift from a management which was confined to an essentially environmental issue, to the public management of a health matter, with several series of measures, starting with the water itself: closure of the most polluted catchments and restricted use of water in the most affected districts, management of network interconnections, distribution of bottled water, installation of activated carbon filtration units by those responsible for the polluted catchments, increased monitoring of water quality. These steps concerned not only drinking water from the tap, but also bottled water: the Capes Dolé company had to cease operation in order to install carbon filters and treat its spring water. After ensuring that no pesticides were present, it was allowed to restart production. ${ }^{22}$

A great deal of publicity was given to these measures, as it was important to inform people about the water contamination and to change their habits where necessary, thus confirming that it was a legitimate problem (press conferences, televised debates). The fact that the risk was made public was largely due to the change of laboratory, which made the previously invisible problem tangible. ${ }^{23}$ It was deemed to be even more worrying in that it revealed products which had been prohibited for a long time, thus raising the question of the duration of past contaminations and of previous works and practices. Whilst wondering about the use of Mirex, chlordecone and $\mathrm{HCH}$, old studies which examined the state of the milieu, in 
particular Snégaroff's publication ${ }^{24}$ and Kermarrec's report ${ }^{25}$ were rediscovered, which then came across as being early alarms or warning signs. ${ }^{26}$ The continued environmental pollution being proven, it was thus water as a milieu and not just as a source of drinking water which was already being discussed. The closure or treatment of drinking water catchments were the first and most visible actions taken. They led to discussions on the question of drinking water standards and on the definition of 'pesticide residue': whilst some people equated 'drinking water' with 'zero chlordecone', the authorities replied that after treatment the residues in the distributed water were well below the standards in force. Here we have the classic argument on the issue of low doses--on the one hand a viewpoint with no toxicity threshold and on the other the defence of a model with a threshold, including safety factors--that can be found in debates relating to other phytosanitary substances (atrazine, etc.) in mainland France. In other words, the question that certain associations were asking was: can one drink water containing very low doses of chlordecone throughout one's lifetime without any negative effects on one's health? The authorities' answer that these waters 'conformed to regulations 27 did not satisfy anyone who felt that chlordecone is, by its very nature, dangerous or carcinogenic. The permanence of aquatic pollution in untreated water, followed by its extension to saltwater and freshwater fishery resources as from 2004, demonstrated the existence of a lastingly contaminated milieu and raised numerous questions as to the pollution spreading. During our time in Guadeloupe, we were thus able to see the concern of farmers from the Grande-Terre region, whose lands are irrigated by waters from Basse-Terre, with regard to the risk of seeing residual pollution gradually passed on to their own farms and produce. On the other hand, as we were reminded in relation to 'wild' springs, due to the invisible nature of pollution and to the 'natural' and non-commercial nature of water available in this manner, it is difficult to make people take notice of preventive publicity against its use. This can be seen in a report on Antilles Television in 2006, where women pay no attention to measures taken to prohibit the use of a spring: 'As you can see, the water is perfectly clear, so not polluted, and that's what we use to prepare our babies' bottles!'

\section{Extension to polluted land: spotting contaminations}

Research into the origin of the water contamination led to the issue of soil contamination and to questions of pollutants being transferred from soil to water. At first the question focused on 
the water: it was a case of measuring contamination levels and of understanding the mechanisms in order to protect the resource from an environmental and health point of view. The results showed contamination from organochlorine pesticides in the soil of banana plantations, even though 'neither the checks themselves, nor the examination of the different documents consulted on site, revealed any irregularities regarding the presence of any prohibited products.' 28 Whilst it exonerated the contemporary producers from any responsibility, the fact that the contamination had been there for some time did not alter the nature of the risk, and it was the land itself which quickly became the object of public attention, creating a second risk, relatively isolated from that of the water. This shift was properly seen for the first time in October 2000 during a meeting of Martinique's departmental hygiene committee, when the proposal for a stance on health, written by doctors and technicians from DDASS (departmental management of health and social affairs) and the Cire unit (inter-regional epidemiology unit) of the InVS (institute of health monitoring), recommended that 'It being likely that farmed soils previously treated with products with a long lifetime ( $\mathrm{HCH} \beta$ and chlordecone) are contaminated, we must ask ourselves whether the animal and vegetable produce from said lands constitute a source of exposure to these molecules, and if so, to what extent. 29

Thus from being a source of water contamination, the soil becomes a potential source of food contamination. This was the reasoning behind the first samples taken for a study carried out in the first half of 2001 for Grephy (regional phytosanitary group), in partnership with farming organisations: they paired off foodstuffs with soils, for example sweet potatoes or dachines, ${ }^{30}$ relying on the skills of the Drôme laboratory. As from February 2002, the state of contamination of the soil, of the dachines, Caribbean cabbages and sweet potatoes was discussed in various institutions; it was also discussed more and more publicly, right up until the prefect's press conference in July. This gradual publicization took place through a partnership between government departments and professional organisations and led to the creation of a legislative framework for the management of 'soil' risk: the 2003 prefectural orders.

These two orders, dated 30 March 2003 for Martinique and 30 October 2003 for Guadeloupe, were similar: before producing edible plants which grow in the soil, the latter had to be analyzed. This is not the place to go into the details of the procedure, which is relatively 
complex due to the highly localized nature of the chlordecone pollution. Suffice it to say that the samples were analyzed in specialised laboratories in mainland France. If they were positive, there was then an analysis of the plants produced, which, where necessary, were either destroyed (Martinique) or not sold (Guadeloupe). The objective was thus to restrict consumer exposure using a measure of an agricultural nature. Whilst the cost had to be borne by the producer, a system was rapidly introduced for the analyses to be funded by the European Union, thus making it easier for this health measure to be implemented.

At the same time as the orders, in Martinique the BRGM (bureau of geological and mining research) and CIRAD (centre for international cooperation in agricultural research) were tasked with developing a model for mapping the risk of soil pollution by organochlorine pesticides. A sampling plan for land plots was established on the basis of an analysis which used three main criteria: the history of the land ownership, parasitical pressure related to rainfall and the soil's capacity for retention. In particular, the analysis was based on three aerial photographs of the banana fields, taken in 1970, 1980 and 1992. The results showed a strong correlation between contamination and banana plantations on the one hand and their duration on the other. ${ }^{31}$ Taking the model on the one hand and the results of the samples required by the order on the other, it was possible to define the zones of risk: 'There is no chlordecone in the soil in areas where chlordecone was not used: no detection of atmospheric contamination or of transfers via runoff waters. If the soil is sound, the plants are sound.' ${ }^{32}$

This result was very important because it made it possible to clearly separate polluted zones from sound zones, thus making it far easier to understand and manage soil risks. The possibility of the contamination being transmitted through repeated contact, anthropologically recurrent, ${ }^{33}$ was not valid for the soils, even where they were washed by waters. On the other hand, the contaminated zones would remain contaminated for a very long time; no remediation was proposed, and people had to think in terms of 'centuries', ${ }^{34}$ at least for certain zones. It would appear that the farming populations took risk measurement very much on board, because we have been told on several occasions that when land is now bought or sold, it is systematically analyzed, in the same way that houses are examined for lead or asbestos. It must be pointed out that such analyses are performed outside of any regulatory framework-they mark the need to rebuild sound territories in a world where contamination is seen as being global. In the same way that Belarusian authorities tried to build in the decade after 
Chernobyl, it is a case of sharing information about what is dangerous and what is not, the threat being invisible and intangible. ${ }^{35}$

\section{The food issue: governed by the principle of precaution}

The land-related risk, environmental at this stage, was thus addressed on two fronts: firstly by constructing scientific mechanisms, be they geographical or agronomical, with which to define a risk probability grid for the contaminated zones/lands/produce. This information was public and was widely shared. The second front was individualized and related to information on a given plot of land or (in a far more limited fashion due to the cost and availability of analyses) on a batch of produce. This information was private and was not shared with the public. Nor was there any information system or any notices displayed on site. It should be added that this distinction between sound and polluted was modified on several occasions, either due to additional contaminated lands being discovered, or because the definition of sound was modified--we will look more closely at this in part two. To the high or low probability of owning land previously used for banana plantations, must therefore be added on the one hand the level of the land's contamination (which can vary enormously over short distances) and variations in the soil-plant transfer, which depend on the soil and plant in question $^{36}$ and, on the other hand, the legal definition of sellable therefore sound.

Whilst the issue of the transfer to plants was at the origin of the soil-related measures, it was not initially a very visible issue, despite public discussions in the summer of 2002 in relation to soil contamination, which we have just described. It was far away from the West Indies that the question of foodstuffs was revealed to a distant audience, three months later, in an article which appeared in the press in mainland France:

'one and a half tons of sweet potatoes, served with chlordecone, a highly toxic pesticide which has been strictly prohibited in France since 1990. [...] But the prohibition must be strictly respected. As matters stand, there is no acceptable threshold or liberty to be taken with the law.' ${ }^{37}$

The article stressed that the issue was governed by a system with no thresholds, the simple presence of chlordecone required the produce to be destroyed.

In the French West Indies, the tests required by the orders relating to land led to measures of the same type: Martinique's plant protection department (SPV) destroyed 14 crops between 
2003 and 2005 and the tests carried out on marketed goods by Martinique and Guadeloupe's DCCRF (Directorate for Competition Policy, Consumer Affairs and Fraud Control) led to the withdrawal of numerous batches due to non-conformity. The effect on producers was twofold: first of all there were major direct financial losses for those who were affected; secondly there were indirect effects on the produce's image. The environmental issue of water pollution thus gradually became more complex, with the addition of an agricultural issue and then a food problem. As more and more anti-chlordecone measures were introduced, the tension between health imperatives and economic logic increased. As far as drinking water was concerned, the existence of drinkability standards and of the technical mechanisms for achieving and checking them made it possible to reach a compromise that was representative of the regulatory system which had been put into place over the previous half century. The situation was very different for foodstuffs, as there were no real data on residue standards.

In the absence of any data, contemporary changes to normative choices thus led French authorities to adopt an explicit principle of precaution which allowed no residue whatsoever, though of course this was dependent on the analyses being effectively carried out and on the extent to which chlordecone was detectable. To this initial stage of events must be added the search for a greater understanding in order to be able to establish standards based upon ordinary data used for expert opinions (toxicity reference values--TRV, maximum residue limit--MRL). The 'zero chlordecone' situation was considered to be a temporary one: in a durably polluted environment, it was now a case of standardising the population's exposure to the foodstuffs. After the mobilization of the specialist mainland laboratories, it was once again actors far from the West Indies who were mobilised to develop the standards.

\section{2/ From precaution to standardisation: building MRLs for chlordecone}

Facing the peculiar situation of rediscovered pollution for which there was no applicable norm, the French government had to build new standards from scratch. Created in 1998 within the context caused by the BSE crisis and the arguments over GMOs, AFSSA was the institution tasked with developing these toxicological standards. It was asked to set an MRL higher than the detection limit of 6 March 2003, to assess the contamination of foodstuffs by organochlorine pesticides in Martinique and in Guadeloupe, and to come up with a TRV. The 
agency responded to these requests in an opinion published on 10 December 2003. ${ }^{38}$ It had used existing scientific literature and the international classification of chlordecone (CIRC) to produce two toxicological references: an acceptable limit for repeated exposure and a maximum limit for acute exposure. But TRVs are theoretical references which do not allow one to directly assess the danger. This can only be achieved by measuring a population's exposure and assessing whether TRVs are exceeded, and at what frequency. In this second section we will analyze, one after the other, two very different ways of doing the calculation, one using local data, the other using quasi-universal considerations, which produce two diverging regulatory systems.

\section{A standard based on 'local data': provisional MRLs for 2005}

In the case of food, exposure depends on the level of contamination of the food and on the amount eaten. The levels of this type of exposure can thus be calculated by cross-referencing the food contamination data with those relating to eating habits (food-buying, frequency of consumption and size of portions). To obtain the latter, an initial study (Escal) was carried out. This study ${ }^{39}$ was a food consumption survey which was carried out in Martinique among approximately 2,000 people, between December 2003 and May 2004, by Cire AntillesGuyane, with help from other organisations (DSDS, Conseil Général, ORS, CGSS). In addition to the socio-demographic details procured, the survey gathered information on foodbuying and consumption. It was thus a very general survey which followed the approach of the first PNSS (national health and nutrition plan) and which had the primary objective of improving knowledge at a time when there was an increase in chronic illnesses and conditions which were to a great extent linked to nutrition (obesity, diabetes, arterial hypertension) and which are very prevalent in the West Indies. The objective of measuring exposure to chlordecone was integrated in an opportunistic fashion into the survey, with particular focus on population groups who ate significant amounts of local produce and who might therefore be contaminated.

At the same time, the monitoring and testing plans introduced by the various administrations involved, as mentioned above, made it possible to analyze root and non-root vegetables, meat and fish, fruit, seafood, milk and eggs. ${ }^{40}$ Despite the resources required (refrigerated transport to mainland France), a large number of analyses were carried out, but with the exception of 
root vegetables the number was nevertheless too low to be deemed representative. There were thus demands for additional specific surveys, leading to the Reso survey starting in September 2005. However, the uncertainties and limits of the contamination surveys did not prevent AFSSA from publishing its report in a context of 'urgent requirement for the populations, local actors and public authorities.' 41

By cross-referencing the two series of data described above, AFSSA made a theoretical assessment of the extent of the exposure by determining a theoretical maximum daily amount, based on local produce. This approach was based on the hypothesis that all of the foodstuffs of local origin which had been consumed and which might have been contaminated, were contaminated to a maximum extent. According to this maximalist method, it appeared to be possible to cover the risk of going over the TRVs for all age categories. However, whilst this scenario indicated the maximum limits which could be tested, it overestimated exposure and was unable to identify the main foods which carried chlordecone and which should be regulated as a priority. Other methods were then used and were able to indicate that the food group carrying the most chlordecone was root vegetables. Results showed that approximately 7 percent of the individuals included in the Escal survey (108 people out of 1495) had higher TRV levels than those recommended by AFSSA, thus justifying the setting of limits for foodstuffs. The report also pointed out the problem of own consumption, given that only marketed foodstuffs were going to be tested: 'In order for the exposure of own consumers to be effectively reduced to acceptable levels, it would appear necessary to combine the setting of MRL with consumption recommendations for own consumption, especially with regard to produce from contaminated zones. ${ }^{42}$

This was the basis on which the new produce standards were defined, in the form of two orders which introduced the agencies recommendations: ${ }^{43}$ foodstuffs of animal origin (5 October 2005) and foodstuffs of plant origin (10 October 2005). The logic behind the standards distinguished between two types of produce, in accordance with their consumption and their contamination: those which were the biggest vectors must have a level of chlordecone below $50 \mu \mathrm{g} / \mathrm{kg}$, the remainder must be below $200 \mu \mathrm{g} / \mathrm{kg}$. This creation of MRLs was presented with caution, due to the uncertainties surrounding contamination (greater than those surrounding consumption). Whilst overall they were well-received, after a long wait, especially by certain farmers in contaminated zones who would once again be able to produce 
certain crops, these initial MRLs were criticised, both for their uncertain basis--backed by the principle of precaution--and for their very theoretical principle. Using the standard criticism of the cumulative effect of substances, this new standard, specific to chlordecone, was a decoy. $^{44}$

Two new surveys provided further knowledge: on the consumption side, Calbas, which replicated Martinique's Escal survey in Guadeloupe; on the contamination side, the Reso survey, developing analyses for numerous foodstuffs. Carried out between November 2005 and July 2006, Reso broadened the range of crops taken into consideration (cucurbitaceous plants for example) and made it possible to analyze plants which were not (or not to any great extent) monitored by government departments (especially own consumption and short circuits). As with the other surveys, Reso was widely presented and discussed in consultation groups such as Grephy and Grepp, and its results were expected. On the basis of Calbas and Reso, AFSSA re-examined the issue of the 2003 TRVs and the 2005 MRLs.

Overall, the estimated levels of chronic exposure among the French West Indian population were lower than those previously assessed, due to the contamination data used being more representative. The Reso surveys were carried out using a random sample of foodstuffs available within distribution circuits whereas the monitoring and testing plans which had initially been used, more particularly targeted foodstuffs and zones likely to be a risk. In addition, AFSSA considered that these results integrated 'the effectiveness of risk control measures already implemented: the prefectural orders issued in 2003 with regard to the preventive analysis of soils, the maximum limit of $0.1 \mu \mathrm{g} / \mathrm{l}$ in drinking water, the provisional maximum limits for food contamination. ${ }^{45}$ However, largely due to own consumption, the agency believed that up to 18.5 percent of children aged between three and five years, and living within contaminated zones, might have gone over the acceptable limit for chronic exposure. So it did not change the MRL, but suggested adding marine produce and Caribbean cabbage to the list of foods with a limit of $50 \mu \mathrm{g} / \mathrm{kg}$. After a lengthy and costly process of data collection and major management steps, the situation thus appeared to have stabilised, both with regard to the risk itself and its standardisation. Yet AFSSA's proposals were not implemented, because at the same time another legislative process was underway. 


\section{A standard with universal scope: the 2007 European MRLs}

In 2006 the European Commission began a process of harmonising the standards for pesticide residues in force in the different member states of the European Union, in accordance with regulation 396/2005/CE of 23 February 2005 relating to the 'maximum limits applicable to pesticide residues present in or on foodstuffs and animal feeds of animal and plant origins.' As chlordecone is listed in annex III of this regulation, the French authorities had to suggest an MRL to the Commission. Initially they tried to escape this legislative framework by declaring that chlordecone was not (or was no longer) a pesticide. In a letter to DG Sanco (Directorate General for Health and Consumer Affairs) dated 5 December 2006, they asserted that chlordecone was an environmental contaminant - just like the mercury used by the wildcat miners in Guyana or the heavy metals produced by factories - and that as such it should be removed from the regulation.

This approach was hardly crowned with success because the European Food Safety Agency (EFSA) based itself on the MRLs recommended by AFSSA to closely examine the case of chlordecone. Whilst AFSSA had based its limits on the specific study of contaminations and consumption in the French West Indies, EFSA projected MRLs for the 26 European food regimes, which allowed it to model population exposures, and its conclusions were irrefutable. Whilst the foodstuffs were all contaminated to MRL levels, the TRVs had been significantly exceeded for the entire population of Europe. As a result, the MRLs could not be accepted. The differences between the two agencies thus stemmed from the ways in which exposure was approached, with on the one hand a realistic model based on the data collected, and on the other hand a theoretical model. ${ }^{46}$ AFSSA and the French authorities argued that the pesticide had not been used for 14 years, and that therefore it was unrealistic to imagine any generalised contamination at MRL level; the European authorities gave France a few months to come up with a full report on the chlordecone MRL.

In the summer of 2007, the chlordecone case changed in nature: the complaints registered in the French West Indies for 'poisoning' began to be relayed at national level and the case was compared to the contaminated blood affair. Upon request from a local association, cancerologist Professor Belpomme compiled a report on the consequences of chlordecone pollution and announced that it would be presented to the French national assembly on 18 September. The media went crazy, first of all when the Ministry of Agriculture declared the 
situation in the West Indies to be 'very serious' and then when Professor Belpomme amplified matters by talking about a 'health disaster' and a situation which was 'worse than that of the contaminated blood affair.' Even though the Minister of Health announced the following day that there was no 'scientific proof', she did call upon people in Martinique and Guadeloupe 'to take the greatest care with regard to produce which does not come from commercial circuits (produce from family vegetable gardens or water taken directly from springs) ${ }^{147}$ and above all announced a new MRL value of $20 \mu \mathrm{g} / \mathrm{kg}$, thus demonstrating the government's determination to strengthen standards by reducing the threshold. Unlike other cases where it had denied that there was a problem or that there were potential consequences, ${ }^{48}$ the French government increased concerns.

However, this proposal for a universal MRL did not convince EFSA and the Commission, who considered that produce cultivated outside the French West Indies and which had no reason to be contaminated, should be standardised by the limit of analytical quantification. On 24 October 2007, the European Commission accepted MRL values lower than those defined in 2005: $20 \mu \mathrm{g} / \mathrm{kg}$ for crops cultivated in tropical or temperate climates (citrus fruit, tropical fruit, all vegetables, corn, sugar cane, etc.) and $10 \mu \mathrm{g} / \mathrm{kg}$ for certain plants specific to regions with temperate climates or which could be imported from countries other than the West Indies (wheat, rice, apples, pears, fruits with stones, sugar beet, etc.). Whether they came from land or sea, animal foodstuffs had to respect a limit of $20 \mu \mathrm{g} / \mathrm{kg}$. These measures were set out in the order of 30 June 2008, which replaced the 2005 orders. Between 2004 and 2008, there had thus been three different MRLs for the same produce: at first root vegetables could not contain any chlordecone, then $50 \mu \mathrm{g} / \mathrm{kg}$, and finally $20 \mu \mathrm{g} / \mathrm{kg}$. So, far from 're-establishing consumer confidence in local produce', these changes in standards had a negative effect on the credibility of assessment measures and risk management, and came in for considerable criticism. Some farmers felt them to be too strict, seeing them as 'excessive precaution' or as an 'umbrella policy'. ${ }^{49}$ Symmetrically, the dual standard of $20 \mu \mathrm{g} / \mathrm{kg}$ for local produce, as against $10 \mu \mathrm{g} / \mathrm{kg}$ for produce from mainland France, fed the theory of governmental laissezfaire or of the authorised poisoning of West Indians, in a period which was marked by health scandals. Some people made repeated demands for MRLs to be removed, which would mean dropping all foodstuffs to $10 \mu \mathrm{g} / \mathrm{kg}$, which is the currently accepted quantification limit and which would take matters back to the situation prior to 2005 . 
So over a period of three years, some products were forbidden, then authorized, then forbidden again as the normative frameworks based on different assemblages of knowledge shifted. From the field perspective, not only is it very difficult to understand, but it also undermines belief in the rightness of such norms, these changes being interpreted as the result of political struggles. If such struggles did exist, we should also highlight the points they had in common, such as the quantification limit of $10 \mu \mathrm{g} / \mathrm{kg}$, which is applied to 'standard' but not to 'advanced' equipment. If the European Commission had taken its reasoning to its logical conclusion, it would not have imposed a precise limit, but rather one which depended on the equipment available. Furthermore, this type of limit is only valid for commercialized products, as these sanitary norms are deeply entrenched within a made-for-market system. ${ }^{50}$

\section{3/ Taking care of the household products: the JAFA program}

The story of chlordecone could end here, being just another episode of the standardization of pollution through regulatory science imposed by experts, governments and economic actors. Nevertheless, the tasks usually undertaken by NGOs on behalf of the population ${ }^{51}$ were in this case carried out by the government, which went far beyond traditional risk communication. How did this happen? In order to understand, we have to go back to the food inquiries which were instrumental in building the first MRLs: they also showed in 2006 that the populations at risk were mainly those who consumed home-grown vegetables cultivated in contaminated soils. Getting in touch with this population, in a context of very heterogeneous pollution and land use, was no easy task and it was indeed costly, thus highly improbable in a French context with little tradition of community health. ${ }^{52}$

\section{Reusing provisional MRLs knowledge}

The context of the health scandal from the autumn of 2007 onwards was the triggering factor that made this improbable program possible. In the 2008 National Chlordecone plan, 3.2 M€ were allocated to build a community public health program 'without parallel in France. ${ }^{53}$ This program was named JAFA for jardins familiaux (family gardens) as the traditional Creole household garden was seen as the main source of risk. It aimed at identifying the 
households potentially overexposed to chlordecone and helping them reduce their exposure by different means. ${ }^{54}$

Initially the program had to rely on distant knowledge of the contamination and reused an updated version of the geographical modelling of the risk based on banana cultivation developed in 2003, including the level of precipitation - correlated with the frequency of pesticide use and the nature of the soil. Limiting the zones to be examined, JAFA promoters crossed the probabilistic model with land ownership maps to come to a figure of 17,887 lots. The fieldwork began with public meetings in all towns concerned, providing information on chlordecone, environmental pollution (water, soil) and its potential sanitary impacts through food, followed by the distribution of leaflets through mail boxes to inform people of the launch of the door-to-door campaign. Fifteen people were hired and given a one-weektraining course on chlordecone, the JAFA program and face-to-face inquiries. They then had to go from lot to lot to find the families who owned and/or cultivated them, suggesting later appointments if they were not present. Despite this flexibility, 36 percent of households in risk zones were not actually interviewed.

Where they succeeded in contacting the families, they handed out a questionnaire asking about the existence of or desire for a household garden, the source of their vegetables and the frequency of their consumption. Once again, the knowledge used for MRLs was reinvested: the threshold was set at a twice-weekly consumption of root vegetables, coming from their garden or that of their neighbours. When they were above this threshold, as was the case for 20 percent of the households, in order to determine the exact levels of chlordecone, a soil analysis was proposed and then processed by local and mainland laboratories within two months. Then, taking a theoretical 20 percent rate of transfer from soil to plant calculated for farmers' products in 2006, the JAFA field workers recommended actions depending on the level of contamination. It went from no restriction of consumption for low levels of chlordecone, to a reminder that it was forbidden to sell the vegetables, and on to a complete stop. The final result was that less than 600 people were affected by such limitations and, as such, really considered to be 'at risk' by official standards.

The approach of the JAFA program is entirely based on an MRL type of knowledge, but built on the 'local science' of soils, plants and consumption. It is an extension of such standardized knowledge to very local conditions--one household, one lot. Contrary to the ETHOS program 
developed for post-Chernobyl contaminated territories, it is not a participatory program: ${ }^{55}$ the aim is less to promote local initiatives and to give people new means to cope and live in their environment, than to treat them with a slightly adapted global standard. As professional farmers, they now know the status of their lot, the only difference being that in some cases, they are 'authorised' to eat food that is not marketable. But in the top to bottom JAFA model, new knowledge can only come from academic expertise, whether on soil remediation or plant transfer.

\section{The limits of standardized management}

The extension of quasi-MRLs to household products needed a lot of material and human investment, at an unprecedented level for the French public health system. The model nevertheless showed its limits by ignoring three important situations. Firstly, there was a limit by design: as the promoters of JAFA themselves acknowledge, some households outside the defined 'risk zones' could be under the threat of chlordecone, as it was used not only for banana weevil, but for other agricultural uses, including low-scale farming. This population must be added to the 'non respondent' households. In a very classic way, promoters consider the hypothesis leading to the recommendations to be very pessimistic, thus stating that 'the population actually over the TRV is probably inferior to the one estimated in the JAFA programme.' 56

The second limit is linked to the behavior of chlordecone. As far as the soil is concerned, it is an incredibly stable molecule: contamination is very localised, thus allowing safe use of the vast majority of the land. If we return to the issue of water transporting chlordecone down the rivers, we find another area of contamination: fish and shellfish. Indeed, the situation is a worrying one, as fishing was forbidden in certain rivers as from 2004, shellfish farms were shut down by authorities from 2007 onwards and high levels of contamination were found in some animals. ${ }^{57}$ Soil leaching models have shown progressive contamination of coastal sea waters. So with their high levels of self-sufficiency, fishing villages were identified as being at risk. And unlike vegetables from Creole gardens, which proved to be less contaminated than expected, sea water is a milieu which homogenizes pollution, thus potentially condemning populations to radically change their consumption habits, something which from an economic standpoint could be costly. Moreover, it may be bad for their health as replacing 
current intake with imported products might increase the rate of metabolic diseases even further - especially diabetes. ${ }^{58}$

The third limit is a socio-political one: vegetables have only been considered in two possible contexts, either as a commodity submitted to MRLs or as a home-grown product 'controlled' by the JAFA program. In fact, there is a very pervasive third context: products sold illegally as part of an informal economy, usually called 'roadside markets'. As it is illegal, no-one has any real idea of its size, though small 'shops' can be seen everywhere along the roads in the French West Indies. Anecdotal evidence also exists:

'We had found a cow with lots of chlordecone, so we went to the farm, which was very small. The old farmer was there with his three cows, next to a stream which was clearly the source of the contamination. And suddenly, on the other side of the stream I saw a huge field of ignames and I asked who the owner was. Nobody knew. I checked the land ownership map, and it was national public domain! An illegal crop of such a size was certainly for the roadside market. 59

This officer had a hard time obtaining authorization for the crop to be analyzed (and maybe destroyed), as 'it was owned by no one, so not destined to market.' The informal economy is crucial to some part of the population and authorities know it, so crucial that even such a mobilization for health has not changed that. Contrary to other policies such as drug enforcement or advertisement for condoms transformed by the AIDS epidemic, it has not been yet sanitized ${ }^{60}$ and remains a larger socio-political issue.

\section{Conclusion: Living in a polluted world}

For two or three decades, French West Indians were totally unaware that their environment was being contaminated by chlordecone. Drinking from a spring or from a tap, eating vegetables or buying them from a local market, required no particular vigilance. The gradual revelation of the state of pollution demonstrated the poison's invasive nature. Just like that of the prion (meat products, but also blood products and medical devices) or radioactivity (mushrooms, thyme, marine produce, etc.), ${ }^{61}$ the gradual circulation of pollution throughout the production, processing and distribution networks created concern and justified legislative action. The realization that land would be gorged with poison for centuries, and its steady progression via leaching of the soil to marine produce, was coupled with that of the 
impregnation of the human body, especially those of pregnant women and young children, studied in cohorts by epidemiologists.

Whilst we already know that MRLs are as much a political tool as a scientific apparatus for treating pollution, ${ }^{62}$ the chlordecone case shows this through the confrontation of two legitimate authorities and their MRLs settings: the French government and the European Commission. But it also begs the question for whom are MRLs made? The pre-2005 precaution caused the ruin of numerous small farmers and threatened consumption of local produce in favour of food regimes which were more expensive and sometimes less nutritious. EFSA found an answer for European consumers, but did nothing to solve the problem for the West Indians, even giving the latter the impression that mainland Europeans were being protected to the detriment of the health of West Indians. The AFSSA standards appeared to be a compromise, but left aside the health of young children and families who were generally at a socio-economic disadvantage and who relied to a considerable extent on own production (vegetable gardens, fishing). It was not directly through social movements, but rather through the threat of a large-scale health scandal that a community health program was developed for them, extending a quasi-MRL regime, but leaving aside other populations (fishermen and those using the informal economy). Nevertheless, a new three-year plan (2011-2013) takes the sea water pollution and the fishing villages into account, and is designed to produce knowledge and ensure surveillance.

Though it has taken public authorities by surprise, the rediscovery of chlordecone has not led to any regulatory crisis. ${ }^{63}$ Even though it took time and different options were explored, it is the regime defined by MRLs which was used to manage the problem of continuous low-dose pollution. Nevertheless, this regime is potentially threatened by two factors. On the one hand, all of the measures were introduced when confronting the potential health effects of the pollution, and not any proven ones. This is not the case anymore, as chlordecone exposure has been epidemiologically linked to prostate cancer, ${ }^{64}$ which was already very high in Caribbean populations. On the other hand, as soil remediation is not yet considered possible and the pollution will last for centuries, it could lead to constant questioning of pollution which exists and is recognised in a very pure form, as the French West Indies have almost no major industrial pollution. A laboratory island, with one substance and human populations, living together with no means of escape. 
${ }^{1}$ In particular, this text owes a great deal to numerous discussions with Eric Godard, inter-ministerial chargé de mission for chlordecone. I would also like to thank the members of the scientific committee on the chlordecone plan for their ever pertinent questions and comments, and Matthieu Fintz and Nathalie Jas for their remarks on the preliminary versions of this text. I am very grateful to Chris Hinton for his translating assistance.

${ }^{2}$ M. J. Beaugendre, Rapport d'information de la Commission des Affaires Economiques, de l'Environnement et du Territoire sur l'utilisation du chlordécone et des autres pesticides dans l'agriculture martiniquaise et guadeloupéenne. Rapport $n^{\circ} 2430$ (Paris: Assemblée Nationale, 2005), p. 91.

${ }^{3}$ R. Carson, Silent spring (Boston: Houghton Mifflin, 1962).

${ }^{4}$ N. Jas in this book.

5 S. Boudia, 'Global Regulation: Controlling and Accepting Radioactivity Risks', History and Technology, 23:4 (2007), pp. 389-406.

${ }^{6} \mathrm{~S}$. Boudia in this book.

${ }^{7}$ S. Jasanoff, The Fifth Branch. Science Advisers as Policymakers (Cambridge: Harvard University Press, 1990).

${ }^{8}$ B. L. Allen, 'Shifting Boundary Work: Issues and Tensions in Environmental Health Science in the Case of Grand Bois, Louisiana', Science as Culture, 13:4 (2004), pp. 429-448.

${ }^{9}$ S. Krimsky, 'From Asilomar to Industrial Biotechnology: Risks, Reductionism and Regulation', Science as Culture, 14:4 (2005), pp. 309-323.

${ }^{10}$ P. Jobin, 'Les cobayes portent plainte. Usages de l'épidémiologie dans deux affaires de maladies industrielles à Taiwan', Politix, 23:91 (2010), pp. 53-75.

${ }^{11}$ B. L. Allen, Uneasy alchemy: Citizens and Experts in Louisiana's Chemical Corridor Disputes (Cambridge, Mass.: MIT Press, 2003).

12 S. Frickel, 'Just Science? Organizing Scientist Activism in the US Environmental Justice Movement', Science as Culture, 13:4 (2004), pp. 449-469.

13 P. Brown, 'Popular Epidemiology Revisited', Current Sociology, 45:3 (1997), pp. 137-156; R.W. Clapp, 'Popular Epidemiology in Three Contaminated Communities', The ANNALS of the American Academy of Political and Social Science, 584:1 (2002), pp. 35-46

14 S. Frickel and M. B. Vincent, 'Hurricane Katrina, Contamination, and the Unintended Organization of Ignorance', Technology in Society, 29:2 (2007), pp. 181-188.

15 F. Chateauraynaud, 'L'épreuve du tangible. Expériences de l'enquête et surgissement de la preuve', Raisons pratiques, 15 (2004), pp. 167-194.

${ }^{16}$ This paragraph refers to the analyses made by M. Fintz, L'autorisation du chlordécone en France 1968-1981 (MaisonsAlfort: AFSSET, 2009).

${ }^{17}$ Beaugendre, Rapport d'information de la Commission des Affaires Economiques, de l'Environnement et du Territoire sur l'utilisation du chlordécone et des autres pesticides dans l'agriculture martiniquaise et guadeloupéenne, p. 19-25. 
${ }^{18}$ H. Bonan and J.-L. Prime, Rapport sur la présence de pesticides dans les eaux de consommation humaine en Guadeloupe, rapport IGAS n²001-070 IGE $n^{\circ} 01 / 007$ (Paris: IGAS, 2001).

${ }^{19}$ P. Balland, R. Mestre and M. Fagot, Rapport sur l'évaluation des risques liés à l'utilisation de produits phytosanitaires en Guadeloupe et Martinique (Paris: Ministère de l'Aménagement du Territoire et de l'Environnement/Ministère de l'Agriculture et de la Pêche, 1998), p. 47.

${ }^{20}$ Balland, Mestre and Fagot, Rapport sur l'évaluation des risques liés à l'utilisation de produits phytosanitaires, p. 49.

${ }^{21}$ We find just one quote on the substance: 'Cirad states it has detected chlordecone (forbidden in 93) at levels of several mg/ L [sic] in the station's tap water.' Balland, Mestre and Fagot, Rapport sur l'évaluation des risques liés à l'utilisation de produits phytosanitaires, p. 50 .

22 Bonan and Prime, Rapport sur la présence de pesticides dans les eaux, p.47.

23 B. Latour, Science in Action: How to Follow Scientists and Engineers through Society (Cambridge Mass.: Harvard University Press, 1987).

24 J. Snegaroff, 'Organochlorines insecticidal residues in soils and rivers of banana-growing regions of Guadeloupe', Phytiatrie \& Phytopharmacie, 26 (1977), pp. 251-267.

25 A. Kermarrec, Niveau de la contamination des chaînes biologiques en Guadeloupe. Pesticides et métaux lourds 1979-1980. Rapport soumis au Ministère de l'agriculture, 1980, at www.antilles.inra.fr [accessed on 11 July 2012].

${ }^{26}$ F. Chateauraynaud and D. Torny, Les Sombres Précurseurs. Une sociologie pragmatique de l'alerte et du risque (Paris: Éditions de l'EHESS, 1999).

${ }^{27}$ DSDS Martinique, La qualité de l'eau potable (Fort de France: DSDS de Martinique, 2008).

${ }^{28}$ Bonan and Prime, Rapport sur la présence de pesticides dans les eaux de consommation humaine, p. 35.

${ }^{29}$ S. Bellec and E. Godard, Contamination par les produits phytosanitaires organochlorés en Martinique : caractérisation de l'exposition des populations (Fort de France: DSDS de Martinique, 2002).

${ }^{30} \mathrm{~S}$. Bellec and E. Godard, Contamination par les produits phytosanitaires organochlorés en Martinique : caractérisation de l'exposition des populations, p. 8.

31 J. Desprats, J. Comte, and G. Perian, Cartographie du risque de pollution des sols de Martinique par les organochlorés. Rapport de phase 2 (Orléans: BRGM, 2003).

${ }^{32}$ Y. Cabidoche, H. Jannoyer, H. Vannière, and M. H. Loulergue, Etat des connaissances sur la contamination des sols et des végétaux par le chlordécone aux Antilles françaises, talk in GREPHY meeting, 17 October 2005.

${ }^{33}$ M. Douglas, Purity and Danger: an Analysis of Concepts of Pollution and Taboo (London: Routledge and K. Paul, 1966).

${ }^{34}$ Y. Cabidoche, C. Clermont Dauphin, R. Achard, A. Caron, P. Cattan, C. Chabrier, A. Lafont, M. Jannoyer and J. Sansoulet, Stockage dans les sols et dissipation dans les eaux de la chlordécone, insecticide organochloré autrefois appliqué dans les bananeraies des Antilles Françaises (INRA-CIRAD, 2006). 
35 A. Pena-Vega, 'Les incertitudes de l'incident de Tchernobyl: L'émergence du sens dans les territoires contaminés en Belarus', Sociétés, 77 (2002) pp. 37-54.

36 Y. Cabidoche, H. Jannoyer and H. Vannière, Conclusions du Groupe d'Etude et de Prospective 'Pollution par les organochlorés aux Antilles'Aspects agronomiques. Rapport INRA-CIRAD, 2006.

37 'Patates douces et toxiques durs', Libération, 16 October 2002.

38 AFSSA, Avis de l'Agence française de sécurité sanitaire des aliments relatif à l'évaluation des risques liés à la consommation de denrées alimentaires contaminées par la chlordécone en Martinique et en Guadeloupe (Maisons-Alfort: AFSSA, 2003).

${ }^{39}$ B. Merle, V. Deschamps, S. Merle, A. Malon, A. Blateau, K. Pierre-Louis, P. Quénel, and K. Castetbon, Enquête sur la santé et les comportements alimentaires en Martinique (Escal 2003-2004); résultats du volet "consommations alimentaires et apports nutritionnels", (InVS, université Paris 13, CNAM, ORS Martinique, 2008).

${ }^{40}$ AFSSA, Avis de l'Agence française de sécurité sanitaire des aliments concernant deux projets d'arrêtés relatifs à la teneur maximale en chlordécone que doivent présenter certaines denrées d'origine végétale et d'origine animale pour être reconnues propres à la consommation humaine (Maisons-Alfort: AFSSA, 2005).

${ }^{41}$ AFSSA, Avis de l'Agence française de sécurité sanitaire des aliments concernant deux projets d'arrêtés relatifs à la teneur maximale en chlordécone, p.13.

${ }^{42}$ AFSSA, Avis de l'Agence française de sécurité sanitaire des aliments concernant deux projets d'arrêtés relatifs à la teneur maximale en chlordécone, p. 28.

${ }^{43}$ AFSSA, Première évaluation de l'exposition alimentaire de la population martiniquaise au chlordecone. Propositions de limites maximales provisoires de contamination dans les principaux aliments vecteurs (Maisons-Alfort: AFSSA, 2005).

44 L. Boutrin and L. Confiant, Chronique d'un empoisonnement annoncé. Le scandale du Chlordécone aux Antilles françaises 1972-2002 (Paris: L’Harmattan, 2007), pp. 152-157.

${ }^{45}$ AFSSA, Avis de l'Agence française de sécurité sanitaire des aliments relatif à la nécessité d'établir des recommandations particulières sur l'allaitement maternel au vu des bénéfices et des risques d'exposition au chlordécone pour les nourrissons martiniquais et guadeloupéens (Maisons-Alfort: AFSSA, 2008).

46 Here we find an opposition analyzed by Marc Barbier with regard to BSE: M. Barbier, 'Une interprétation de la constitution de l'ESB comme problème public européen', Revue internationale de politique comparée, 10:2 (2003), pp. 233-246.

${ }^{47}$ AFP, 18 September 2007.

48 G. Markowitz and D. Rosner, Deceit and denial: the deadly politics of industrial pollution (Berkeley and London: University of California Press, 2002).

${ }^{49}$ D. Torny, 'L'administration des risques sanitaires face à l'éloignement de l'expertise: le cas français au tournant des années 2000', Sociologies et société, 39:1 (2007) pp. 181-196. 
50 D. Pestre, 'The Historical Heritage of the 19th and 20th Centuries: Techno-science, Markets and Regulations in a Longterm Perspective', History and technology, 23:4 (2007), pp. 407-420.

${ }^{51}$ Frickel, 'Just science?'.

52 D. Fassin, 'Public Health as Culture. The Social Construction of the Childhood Lead Poisoning Epidemic in France', British Medical Bulletin, 69:1 (2004), pp. 167-177.

53 Public health officer, personal communication, October 2008.

54 The description of the JAFA program and results is based on: J. Vincent, D. Camy, G. Thalmensi, M. Julien, M. Ledrans, P. Quénel, A. Blateau and E.Godard, 'Le programme de santé des Jardins Familiaux en Martinique. Bilan d'étape et perspectives', $B A S A G, 10$ (2010), pp. 2-9.

${ }^{55} \mathrm{~S}$. Topçu, in this book.

56 Vincent, Camy, Thalmensi, Julien, Ledrans, Quénel, Blateau and Godard, 'Le programme de santé des Jardins Familiaux en Martinique. Bilan d'étape et perspectives'.

${ }^{57}$ AFSSA, Avis de l'Agence française de sécurité sanitaire des aliments relatif à l'actualisation des données scientifiques sur la toxicité du chlordécone en vue d'une éventuelle révision des limites tolérables d'exposition proposées par l'Afssa en 2003 (Maisons-Alfort: AFSSA, 2007).

58 InVS-Inserm, Impact de l'utilisation du chlordécone aux Antilles françaises : Recommandations pour les recherches et les actions de santé publique à mettre en oeuvre (Paris : InVS-Inserm, 2009).

${ }^{59}$ Public Health officer, personal communication, October 2008.

60 D. Fassin, 'The Politics of Life: Beyond the Anthropology of Health' in F. Saillant and S. Genes (eds.), Medical anthropology: regional perspectives and shared concerns (Malden: Blackwell Publishing Ltd, 2006), pp. 253-266.

${ }^{61}$ Chateauraynaud and Torny, Les Sombres Précurseurs.

62 B. Gillespie, D. Eva and R. Johnston, 'Carcinogenic Risk Assessment in the United States and Great Britain: The Case of Aldrin/Dieldrin', Social Studies of Science, 9:3 (1979), pp. 265-301; H. Rothstein, A. Irwin, S. Yearley and E. McCarthy, 'Regulatory Science, Europeanization, and the Control of Agrochemicals', Science, Technology \& Human Values, 24:2 (1999), pp. 241-264; R. Diggle, 'Regulatory science and uncertainty in the risk assessment of pesticide residues' (PhD thesis: University of Nottingham, 2010).

63 D. Demortain, 'From drug crises to regulatory change: The mediation of expertise', Health, Risk \& Society, 10:1 (2008), pp. $37-51$.

${ }^{64}$ L. Multigner and al., 'Chlordecone Exposure and Risk of Prostate Cancer', Journal of Clinical Oncology, 28:21 (2010), pp. 3457-3462. 